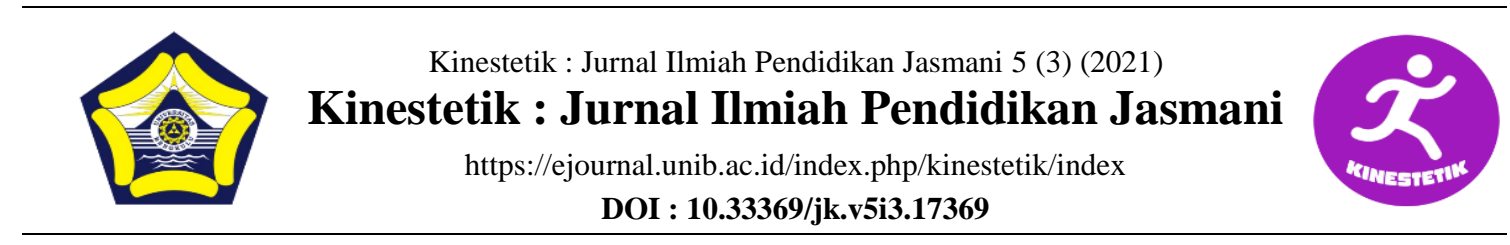

\title{
SCUBA LEARNING VIDEO FOR DIVING COURSES
}

\author{
Ayu Rahayu ${ }^{1 *}$, Arief Nuryadin ${ }^{2}$, Ridwan Afrizal $^{3}$, Amal Maftuh Khoiri ${ }^{4}$ \\ ${ }^{1234}$ Department Of Sport Science, Faculty Of Medicine, Sultan Ageng Tirtayasa University, \\ Banten, Indonesia
}

\begin{tabular}{l} 
Article Info \\
\hline Article History : \\
Received : August 2021 \\
Revised : September 2021 \\
Accepted : September 2021 \\
Available online : September \\
2021
\end{tabular}

Keywords:

SCUBA Diving, Learning, Video

\begin{abstract}
SCUBA diving is one of the studies that must be mastered by students taking Diving courses in the UNTIRTA Sports Science Study Program, especially students who will take the Sport Tourism concentration. This research aims to develop SCUBA learning video as an alternative long distance learning media for diving courses in Pandemic Covid-19. Procedure in this research used refers to the 4D model with 4 stages, namely define, design, develop, and disseminate. The instruments used in this research include observation sheet, media expert validation questionnaire, material expert validation questionnaire, small-scale \& large-scale trial questionaire. Participants in this research activity were 3 media experts, 3 material experts (diving instructur ADSI, POSSI, \& SSI), 9 students for small-scale trials and 26 students for large-scale trials. Students who conduct small-scale and large-scale trials are students of the 2020 class of sports science study program who will take diving course. The data collection techniques in this research were carried out by recapitulating and analyzing the results of the questionnaire from all participants so that the final product was obtained. Based on the results of the assessment of media experts, material experts, the results of small-scale and large-scale trials, SCUBA learning video is in the very worth it (feasible) category in terms of media and material aspects so that it can be an alternative distance learning media for diving courses, especially the subject SCUBA Diving.
\end{abstract}

\begin{tabular}{llr}
\hline Corresponding address & : D’Mutiara Residence Blok A 22 & ISSN 2685-6514 (Online) \\
Pandeglang & & ISSN 2477-331X (Print) \\
*Corresponding email & : ayurahayu @untirta.ac.id &
\end{tabular}




\section{INTRODUCTION}

SCUBA (Self Contained Underwater Breathing Apparatus) diving is a very popular diving mode in recent decades. This dive mode is characterized by a number of special equipment or SCUBA sets that are carried by divers when diving underwater (Kintz et al., 2017). SCUBA set or equipment consist of SCUBA tank (filled), buoyancy compensator, weight system, regulator with pressure gauge, alternate air source, and some other additional equipment such as mask, snorkel, and snorkel keeper, fins and boots, exposure suit, hood, and gloves, instruments to monitor depth, time, and direction (Graver, 2016).

Seeing the beauty of the underwater world firsthand makes diving a sport that has an impact on mental health. SCUBA diving has a positive impact on human mental health (Lucrezi et al., 2018), improvement of cardiorespiratory fitness (Azis et al., 2021), and physical health of people with physical disabilities (Henrykowska et al., 2021). In line with this, based on Law Number 3 of 2005 concerning the National Sports System, SCUBA diving is included in the category of recreational sports. In Indonesia, the parent organization of SCUBA Diving is known as the All-Indonesian Diving Association (POSSI). In the word.

SCUBA diving is one of the studies that must be mastered by students taking Diving courses in the UNTIRTA Sports Science Study Program, especially students who will take the Sport Tourism concentration. In this study, students are expected to be able to understand the meaning, history, and development of SCUBA diving, understand the types and functions of SCUBA Set/Equipment and their installation procedures, understand entry procedures into water/sea depths, mask clearing and equalizing.

Given the underwater environment is an extreme environment and the use of equipment is quite complex, the diving procedure must be carried out properly and correctly. Decompression Sickness (DCS) and Pulmonary Over inflation Syndrome (POIS) are one of the risks of injury associated with scuba diving (Hall, 2014). So, SCUBA diving can be a dangerous sport (Coop et al., 2016). Mistakes in dive preparation in such an environment can lead to unsafe conditions, accidents, injuries and even death (Ranapurwala et al., 2017). Therefore, it is very important to understand the function and installation of scuba equipment properly, because it is related to safety.

Learning activities in diving courses, especially in the study of SCUBA diving, should be held face-toface or offline, considering that there are several special skills/skills that students need to master. However, due to the ongoing COVID-19 pandemic, the form of learning has shifted from offline to be an online form of learning. Therefore, teachers need to choose and consider the type of learning media that will be used in the subject of this study so that learning activities can take place optimally even 
though the form of learning is not in offline form.

Learning video is one form of presenting material that is widely used in learning activities during the covid-19 pandemic and one of the most common learning media to present a theoretical concept (Jordán et al., 2021). Using learning videos can make it easier for teachers to deliver material and make it easier for students to understand learning materials (Ridha et al., 2021), increase the knowledge (Wiliyanarti et al., 2021), make the learning environment more attractive than using only textbooks (Nashar et al., 2020). Moreover, using learning video effective in improving student's learning outcomes (Fitriansyah, 2020), increase students' motivation and active learning which also has a direct impact on improving student learning outcomes, especially in the distance learning (Susmiati, 2020).

This opinion is in line with the results of a survey at UNTIRTA sports science students in October 2020, where it is known that as many as $88.9 \%$ of respondents have an audio-visual learning style, and only $11.2 \%$ have a visual learning style. In choosing the type of learning media, $63.9 \%$ of respondents chose video as the most convenient learning media to use, especially during the Covid-19 pandemic. In addition, the undeveloped learning media for diving courses in the form of SCUBA Learning Video is also the main reason for this research development. The learning video as a result of this development is expected to be an alternative media for distance learning in diving courses, especially on the subject of SCUBA Diving.

\section{METHODS}

The development procedure for the 4-D model includes four stages, including define, design, develop, and disseminate develop by Thiagaradjan (in Rahayu \& Nurcahyo, 2020).

\section{Participants}

The participants in this research activity were 3 media experts, 3 material experts (diving instructur ADSI, POSSI,\& SSI), 9 students for small-scale trials and 26 students for large-scale trials. Students who conduct small-scale and large-scale trials are students of the 2020 class of sports science study program who will take diving course.

\section{Sampling Procedures}

The research location consists of several places, including the following: (1) Location for taking pictures/videos part 1 is on Sepolwan Swimming pool, (2) Location for taking pictures/videos part 2 is on Peucang Island. This location was chosen because first, on Sepolwan Swimming pool and Peucang Island there is a Dive Center that provides diving equipment that can support the process of making videos. Second, Peucang Island is one of the locations that will be diving practice for sports science students who are taking diving courses, (3) Location of the small-scale and large-scale trials is carried out in the Sport Science Study Program, UNTIRTA. 


\section{Materials and Apparatus}

The instruments used in this study include: Observation sheet, media expert validation questionnaire, material expert validation questionnaire, small-scale trial questionnaire and large-scale test questionnaire.

\section{Procedures}

The procedure used in this research refer to 4D model develop by Thiagaradjan (in Rahayu \& Nurcahyo, 2020) that can be seen in Figure 1 below:

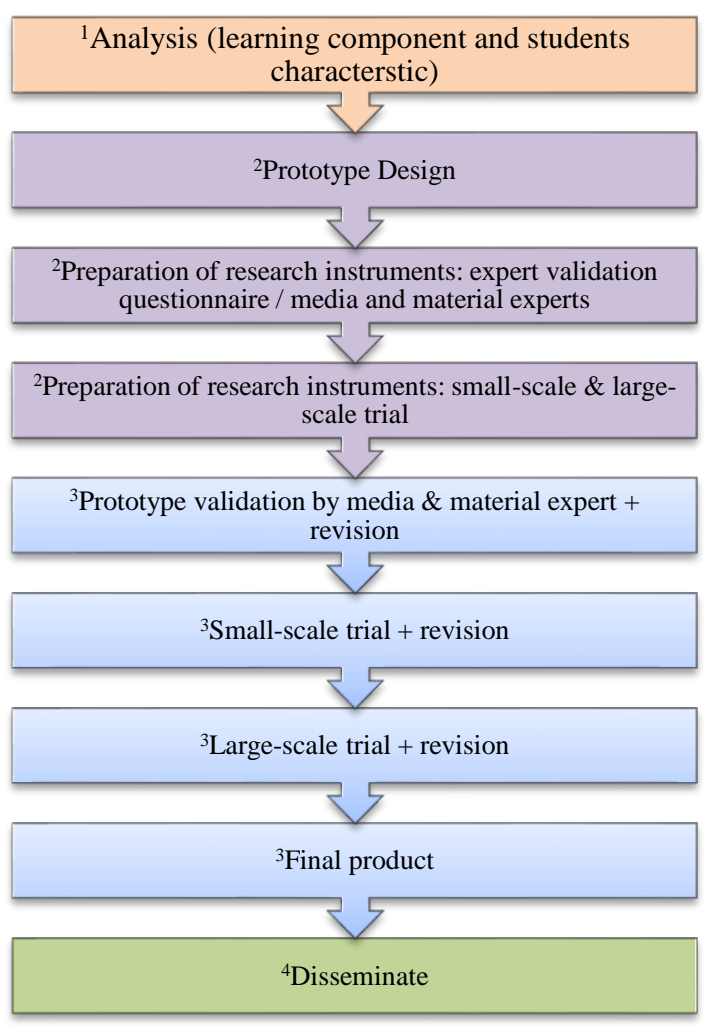

Note: $1=$ Define, $2=$ Design, $3=$ Develop, 4=Disseminate

Figure 1. Schematic of the 4D model

1. Define

The define stage consists of two activity steps, namely the analysis of learning components and analysis of the characteristics of students of the sport science study program. Analysis of learning components is done by analyzing matters related to learning such as reviewing the curriculum, syllabus, Semester Implementation Plan, teaching materials and learning resources, as well as observing supporting facilities and infrastructure in diving courses. While the analysis of student characteristics is carried out by observing the process of lecture activities for 4 meetings (online) to find out the styles and patterns of student learning.

2. Design

The design stage consists of two activity steps, including the preparation of the initial format of the development media (script, determining the duration of the video, determining the location for taking pictures and videos, video editing) and research instruments in the form of a validation questionnaire, a small group test questionnaire (limited), and a pilot test. large group (field). This stage produces the initial product (prototype).

3. Develop

The procedure carried out at the development stage is to validate the initial product developed (prototype) on 3 media experts and 3 material experts to determine the quality of the developed media both from the media and material aspects. The results of the validation from the media and material experts then will be analyzed and revised if there are suggestions/ improvements. Furthermore, the revised product development results based on suggestions and input from media and material experts/experts will be tested in small-scale and large scale trial. The results of the trial at this stage will then be revised according to the suggestions and inputs that have been given. The final result at this stage is the final product that is ready to be distributed. 
4. Disseminate

The dissemination phase is planned to be carried out in several study programs that provide diving courses.

\section{Design or Data Analysis}

The data analysis technique in this development research refers to the Mardapi (in Rahayu \& Nurcahyo, 2020), that is:

1.Collecting and converting score data on the questionnaire sheet into qualitative form (score $4=$ very good, score $3=$ good, score $2=$ poor, score 1 = very poor)

2.Calculate the average score of the total filling in the questionnaire using the following formula:

$$
\bar{X}=\frac{\sum X}{n}
$$

Note: $\bar{X}=$ Mean Score, $\Sigma X=$ Total

Score, $\mathrm{n}=$ number of appraisers

1. Converting the average score into a qualitative value with criteria:

Table 1. Convert Average Score Into Qualitative

\begin{tabular}{ccl}
\multicolumn{1}{c}{ Form } & \\
\hline $\mathrm{x} \geq \bar{X}+1 \mathrm{SBi}$ & $\begin{array}{c}\text { Score/ } \\
\text { value }\end{array}$ & Category \\
\hline $\bar{X}+1 \mathrm{SBi}>\mathrm{x} \geq \bar{X}$ & 3 & very worth it \\
\hline $\bar{X}>\mathrm{x} \geq \bar{X}-1 \mathrm{SBi}$ & 2 & no worthy \\
\hline $\mathrm{x}<\bar{X}-1 \mathrm{SBi}$ & 1 & no feasible \\
\hline
\end{tabular}

Note:

$\mathrm{X}=$ score obtained,

$\bar{X}=$ rata-rata ideal $=1 / 2(4+1)=2,5$

$\mathrm{SBi}=1 / 5(4-1)=0,6$

\section{RESULTS}

The result of this development research is a SCUBA learning video for diving courses (duration $=38.15$ minutes), with three session: session 1 (history of diving, skin diving equipment \& procedure), session 2 (SCUBA Equipment, Instalation /Release procedur, Entry Procedure, Mask Clearing \& Equalizing), and session 3 (SCUBA diving designation). Based on the results of the assessment of media experts, material experts, the results of small-scale and large-scale trials, SCUBA learning video is in the very worth it (feasible) category in terms of media and material aspects so that it can be an alternative distance learning media for diving courses, especially the subject SCUBA Diving.

\section{Tables \& Figures}

The SCUBA Learning Video screen display can be seen in the following figures 2-15 below:

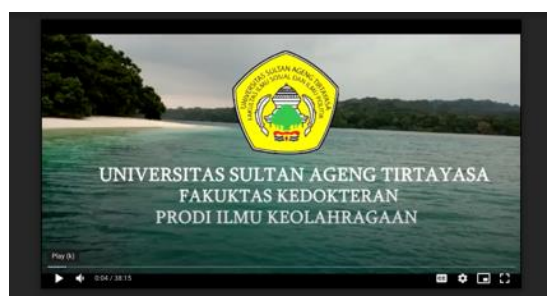

Figure 2. Opening Scene

Figure 2 is an opening scene display that shows the identity of the institution. This scene is 6 seconds long.

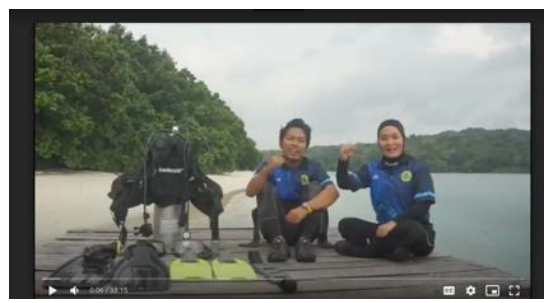

Figure 3. Prolog

Figure 3 is a prologue scene display that displays a brief description of the instructional video usage guide. This scene is 2 minutes long. 


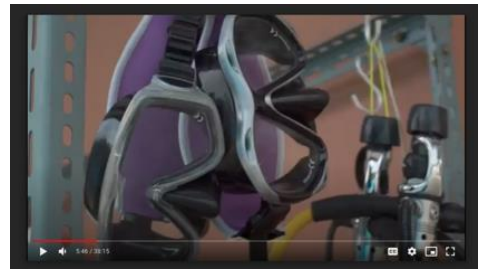

Figure 4. Skin Diving Equipment

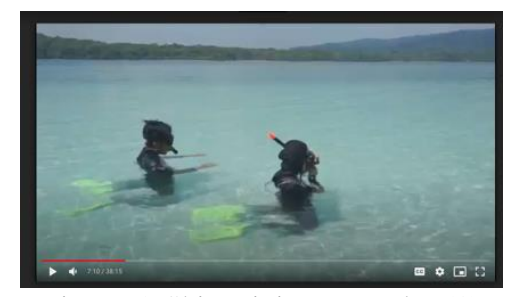

Figure 5. Skin Diving Procedur (1)

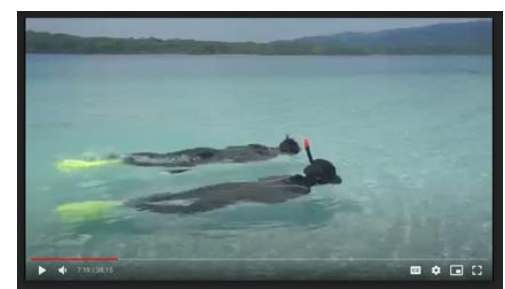

Figure 6. Skin Diving Procedur (2)

Figures 4, 5, \& 6 are screen displays in video session 1 , history of diving, skin diving equipment \& equipment. This scene is 6 minutes long.

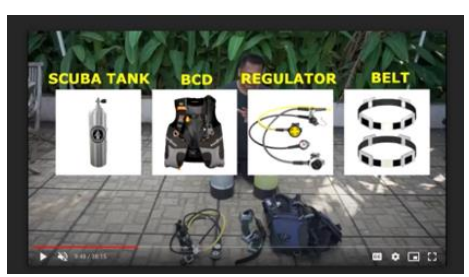

Figure 7. SCUBA Diving Equipment

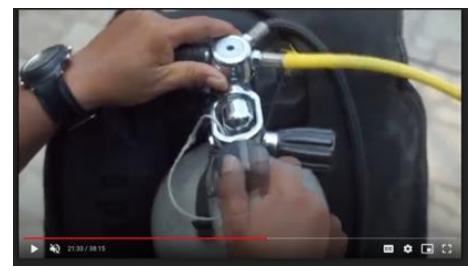

Figure 8. Instalation Procedure (before diving)

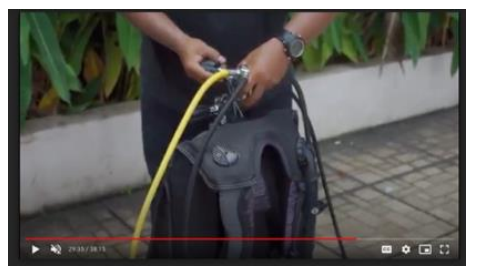

Figure 9. Release Procedure (after diving)

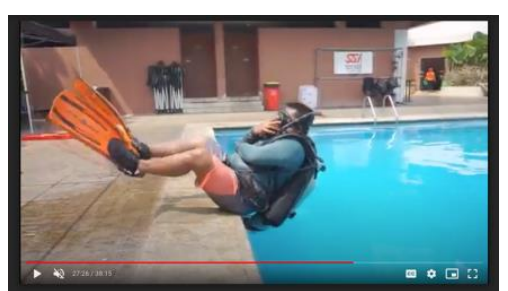

Figure 10. Entry Procedure into Pool

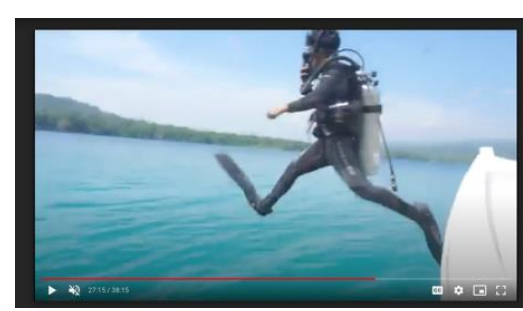

Figure 11. Entry Procedure into the sea

Figure $7-11$ is a screen shot in video session 2, SCUBA Equipment, Installation/Release procedure, Entry Procedure, Mask Clearing \& Equalizing). This scene is 21 minutes long.

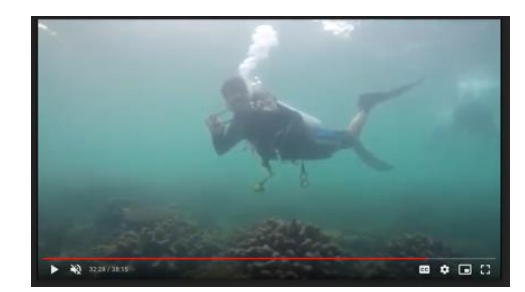

Figure 12. SCUBA Diving for Recreation

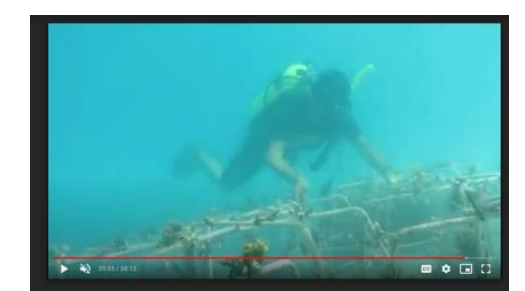

Figure 13. SCUBA Diving for Conservation

Figure $12-13$ is a screenshot in video session 3, SCUBA Diving Designation. This scene is 6 minutes long.

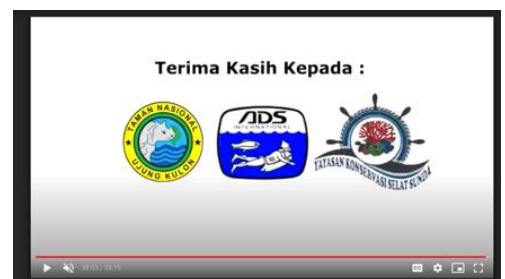

Figure 14. Closing Scene (1) 


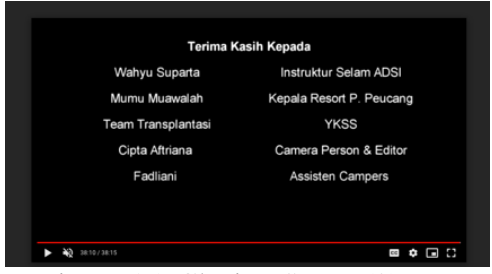

Figure 15. Closing Scene (2)

Figure 14-15 is the closing screen display. This scene is 10 seconds long. This scene is ending of SCUBA Learning Video.

The data on the results of the media assessment by media and material experts can be seen in table 2 . While the data on the results of small and large scale trials can be seen in table 3 .

Table 2. The quality of the media in terms of the results of the assessment of media and material experts

\begin{tabular}{ccc}
\hline Validator & $\begin{array}{c}\text { Mean Score } \\
\text { Total }\end{array}$ & Category \\
\hline Media Expert & 3.2 & Very worth it \\
\hline Material Expert & 3.8 & Very worth it \\
\hline
\end{tabular}

The data in table 2 shows that based on the results of assessments from media experts and material experts, the quality of the learning videos developed as a result of the development is in the very worth it category in terms of media and material aspects.

Table 3. The quality of the media in terms of the results of the small-scale and large scale trial

\begin{tabular}{cccc}
\hline Trial & $\begin{array}{c}\text { Indikator/ } \\
\text { Aspec }\end{array}$ & $\begin{array}{c}\text { Mean } \\
\text { Score } \\
\text { Total }\end{array}$ & Category \\
\hline Small & Media & 3.7 & Very worth it \\
\cline { 2 - 4 } Scale & Materi & 3.8 & Very worth it \\
\hline Large & Media & 3.8 & Very worth it \\
\cline { 2 - 4 } Scale & Materi & 3.9 & Very worth it \\
\hline
\end{tabular}

The data in table 3 shows that based on the results of small-scale and large-scale trials, the quality of the learning videos developed is in the very worth it category in terms of media and material aspects.

\section{DISCUSSION}

Using of learning videos not only has a positive impact on increasing learning success for both teachers and students, but also in terms of professional development (Sablić et al., 2020). The use of learning videos can also help make it easier for students to understand information when re-watching previously watched videos (Seo et al., 2021). Therefore, further research is needed regarding the effectiveness of its use in distance learning activities, for example to determine interest and learning achievement, as well as the level of understanding of students concepts during learning activities using SCUBA learning video.

\section{CONCLUSION}

Based on the results of the assessment of media experts, material experts, the results of small-scale and large-scale trials, SCUBA learning video is in the very worth it (feasible) category in terms of media and material aspects so that it can be an alternative distance learning media for diving courses, especially the subject SCUBA diving.

\section{ACKNOWLEDGEMENT}

Thank you to the diving instructors from ADSI, POSSI and SSI, Ujung Kulon National Park Center (Peucang Island Resort) and the team from the Sunda Strait Conservation Foundation (YKSS) who have been willing to provide assistance and direction during the process of making videos so that scuba diving learning videos are made. from UNTIRTA's sports science study program can be carried out well. 


\section{REFERENCES}

Azis, N. N. N., Karim, S. A., Mohamad, M., \& Mustafah, N. M. (2021). Effect of recreational scuba diving on cardiorespiratory fitness in malaysian novice divers. Journal of Health and Translational Medicine, 24(1). https://doi.org/10.22452/jummec.vol24 no1.12

Coop, C. A., Adams, K. E., \& Webb, C. N. (2016). SCUBA Diving and Asthma: Clinical Recommendations and Safety. In Clinical Reviews in Allergy and Immunology (Vol. 50, Issue 1). https://doi.org/10.1007/s12016-0158474-y

Fitriansyah, F. (2020). Effectiveness of Video Learning Development Announcing. International Journal of Theory and Application in Elementary and Secondary School Education, 2(1). https://doi.org/10.31098/ijtaese.v2i1.67

Hall, J. (2014). The risks of scuba diving: a focus on Decompression Illness. Hawai'i Journal of Medicine \& Public Health: A Journal of Asia Pacific Medicine \& Public Health, 73(11).

Henrykowska, G., Soin, J., \& Siermontowski, P. (2021). Scuba diving as a form of rehabilitation for people with physical disabilities. International Journal of Environmental Research and Public Health, 18(11). https://doi.org/10.3390/ijerph18115678

Jordán, J., Valero, S., Turró, C., \& Botti, V. (2021). Using a hybrid recommending system for learning videos in flipped classrooms and moocs. Electronics (Switzerland), 10(11). https://doi.org/10.3390/electronics1011 1226

Kintz, P., Garnier, J. F., Brunet, B., Mura, P., \& Raul, J. S. (2017). Cannabis and scuba diving. About 2 cases with fatal outcome. Toxicologie Analytique et Clinique, 29(3). https://doi.org/10.1016/j.toxac.2017.03. 123

Lucrezi, S., Egi, S. M., Pieri, M., Burman, F., Ozyigit, T., Cialoni, D., Thomas, G., Marroni, A., \& Saayman, M. (2018).
Safety priorities and underestimations in recreational scuba diving operations: A European study supporting the implementation of new risk management programmes. Frontiers in Psychology, 9(MAR). https://doi.org/10.3389/fpsyg.2018.003 83

Nashar, N. A. B., Jumintono, Pudyastuti, R. R., Handayani, E., Indarto, M. R., Sunardi, J., Retnowati, N. D., \& Sawitri, S. (2020). Increasing understanding of general knowledge of plastics with video-based learning. Universal Journal of Educational Research, 8(11). https://doi.org/10.13189/ujer.2020.0822 25

Ranapurwala, S. I., Wing, S., Poole, C., Kucera, K. L., Marshall, S. W., \& Denoble, P. J. (2017). Mishaps and unsafe conditions in recreational scuba diving and pre-dive checklist use: a prospective cohort study. Injury Epidemiology, 4(1). https://doi.org/10.1186/s40621-0170113-z

Ridha, M., Firman, \& Desyandri. (2021). Efektifitas Penggunaan Media Video pada Pembelajaran Tematik Terpadu di Sekolah Dasar Saat Pandemi Covid-19. Jurnal Pendidikan Tambusai, 5(1).

Sablić, M., Mirosavljević, A., \& Škugor, A. (2020). Video-Based Learning (VBL) Past, Present and Future: an Overview of the Research Published from 2008 to 2019. Technology, Knowledge and Learning. https://doi.org/10.1007/s10758-02009455-5

Seo, K., Dodson, S., Harandi, N. M., Roberson, N., Fels, S., \& Roll, I. (2021). Active learning with online video: The impact of learning context on engagement. Computers and Education, 165.

https://doi.org/10.1016/j.compedu.2021 .104132

Susmiati, E. (2020). Meningkatkan Motivasi Belajar Bahasa Indonesia Melalui Penerapan Model Discovery Learning dan Media Video Dalam Kondisi Pandemi Covid-19 bagi Siswa SMPN 2 Gangga. Jurnal Paedagogy, 7(3). 
https://doi.org/10.33394/jp.v7i3.2732

Undang-Undang Nomor 3 tentang Sistem

Keolahragaan Nasional Tahun 2005

tentang Sistem Keolahragaan Nasional

Pasal 1 ayat 12 dan 13 tentang olahraga rekreasi dan olahraga prestasi. https://www.dpr.go.id/dokjdih/docum ent/uu/45.pdf [Tanggal akses 22 Agustus 2021]

Wiliyanarti, P. F., Yuliyanasari, N., \& Martati, B. (2021). The Influence of Learning Video Media On Protocol Health Knowledge Covid-19 Elementary School Students. Strada, 10(1). 